\title{
Vegetative Propagation of Punica granatum by Stem Cuttings Using Non-Mist Propagator
}

\author{
Md. Alamgir Kabir*, Mahamud Hasan Prince, Rezaul Karim, Saifur Rahman, K.M. \\ Masum Billah, G.N. Tanjina Hasnat \\ Patuakhali Science and Technology University, Bangladesh. \\ *Corresponding author e-mail: alamgirmk@gmail.com
}

\begin{abstract}
How to Cite: Kabir, M.A., Prince, M.H., Karim, R., Rahman, S., Billah, K.M.M., \& Hasnat, G.N.T. (2017). Vegetative Propagation of Punica granatum by Stem Cuttings Using Non-Mist Propagator, Int. J. Agr. Syst. 5(2): 185-197.
\end{abstract}

\begin{abstract}
The present study was carried out to explore rooting performance of Punica granatum (Dalim) in Bangladesh through clonal propagation by stem cutting under 3 different doses of rooting hormone IBA (Indole Buetairic Acid) and planted in the perforated plastic tray filled with coarse sand and gravel placed in the non-mist propagator. The experiment was laid out following a Randomized Complete Block Design (RCBD) with 4 treatments and 4 replications (blocks). The treatments were $\mathrm{T} 0=$ control, $\mathrm{T} 1=0.2 \% \mathrm{IBA}, \mathrm{T} 2=0.4 \% \mathrm{IBA}, \mathrm{T} 3=0.8 \% \mathrm{IBA}$. The rooting ability of cuttings was significantly influenced by the application of IBA. The results showed that the highest rooting percentage $(70 \%)$ and longest root length $(11.75 \mathrm{~cm})$ of $P$. granatum stem cuttings were obtained from the cuttings treated with $0.2 \%$ IBA followed by $0.4 \%$ IBA $(47.5 \%$ and $7.95 \mathrm{~cm}$ respectively) whereas the highest root number (32) and maximum root diameter $(2.7 \mathrm{~mm})$ were recorded with $0.4 \% \mathrm{IBA}$ followed by $0.8 \%$ IBA (28 and $2.47 \mathrm{~mm}$ respectively). Survival percentage of the cutlings (the rooted cuttings) after 3 months of transferring them into poly bags was also significantly enhanced by exogenous rooting hormone (IBA) application. The highest survival percentage $(73.5 \%)$ was observed with $0.4 \%$ IBA treatment followed by $0.8 \%$ IBA (68.5\%). Findings of the present study reveal that $P$. granatum is highly amenable for clonal propagation by stem cuttings using low-cost non-mist propagator and $0.4 \%$ IBA treatment may be recommended for mass production of quality planting stocks for the cultivation of the species in homestead agroforestry or in fruit orchards. These outcomes can assist to provide edible fruit to poor rural people of natural disaster vulnerable Bangladesh.
\end{abstract}

Copyright @2017 IJAS. All rights reserved.

Keywords:

Punica granatum; IBA; clonal propagation; non-mist propagator

\section{Introduction}

A large portion of Bangladeshi people are poorly nourished and suffers from low micronutrient intake due to poor dietary diversity and inadequate consumption of nutrient rich foods. Fruits are a natural source of essential micronutrients, because of which they are indispensable element in the human diet. Despite ample increase of food production over past few decades in the country, a vast number of people still 
suffer from malnutrition and consequential diseases. This is due to the fact that cereals contribute 70 percent to the total dietary energy intake in Bangladesh.

Fruits are crucial in daily diet as they add variations in the diet, improve the palatability of staple foods and provide essential vitamins, minerals, fiber, proteins, carbohydrates, fats and bioactive compounds. Fresh fruits ensure as well as increase dietary diversity among the people and confirm insurance against malnutrition. But, they are consumed in limited quantities compared to main food staples due to higher price and seasonal unavailability.

Pomegranate (Punica granatum L.), commonly known as "Dalim", belongs to a distinct family "Punicaceae" is one of the most important fruits of the tropical and subtropical region. It has been widely cultivated since ancient times throughout Iran, India, south-east Asia, Malaya, United States and Latin America etc. They are deciduous under subtropical and evergreen under tropical conditions. Being hardy in nature, pomegranate tree can withstand adverse climatic conditions such as severe colds, salinity, drought etc. and has wide adaptability under tropical conditions.

The plants are shrub or small trees $(6-10 \mathrm{~m})$ and largely crooked. Leaves may be clustered, opposite or sub opposite on small axillary branchlets, leaves shiny, dark green and shining above and light green below. Fruit is a round/globose berry with persistent calyx also with remnant of style and stamens. Seeds are angular, hard to soft (Singh, 2017).

Generally, there are three flushes each of which may result in flowering. Under subtropical conditions, it flowers in spring along with a flush of vegetative growth. Fruits of this flush ripen late in summer, whereas the vegetative flush during same period flowers in the next spring.

Pomegranate fruit is greatly cherished for its dietary and pharmaceutical properties like high antioxidant contents, antimicrobial, antiviral, anticancer, anti-mutagenic and anti-cardiovascular disease properties etc. (Negi et al., 2003 and Seeram et al., 2005). It is vastly used as table fruit, salad, in preparing fruit mix, juice, jam, jelly or bevera ges. It is rich in vitamins, minerals, antioxidants and tannins. Pomegranate juice is an exceptional source of vitamins ( $\mathrm{B}$ and $\mathrm{C}$ ), sugars, minerals ( $\mathrm{K}$ and $\mathrm{Fe}$ ) and antioxida $\mathrm{nt}$ polyphenols (ellagic acid and punicalagin) which not only lower cholesterol but also lowers blood pressure and prevent both heart attacks and strokes (Aviram et al., 2004, Karimi and Mirdehghan, 2013).

Pomegranate plants can be propagated either sexually by seeds or asexually by stem cuttings, layering, bottom sprouts and grafting (Polat and Caliskan, 2009). Tissue culture is another method of production that calls for the grow th of the plant in a sterile environment using the tissue, seed, or cuttings (Abdelrahman and AI-Wasel, 1999). Seed-raised plants show a great variability with regard to tree vigour, precocity and quality of fruits. Therefore, vegetative propagation is utmost desirable to propagate true to type plants (Kaur and Kaur 2016). Basically in agroforestry, the improvement of the existing systems should include species' selection and access to quality germplasm (Hoang et al. 2017). However, in commercial propagation stem cuttings are exten sively used as it is the most convenient and low-cost method of attaining a fully established healthy tree in considerably less time. Moreover, exogenous application of IBA encourages rooting in stem cuttings and in air layers owing to their ability to active cambium regeneration, cell division and cell multiplication (Rymbai and Reddy, 2010). Ironically, information about the artificial regeneration of $P$. granatum in Bangladesh through vegetative propagation by stem cutting is very scarce. Extensive research in this aspect is needed as farmers are becoming reluctant day by day to cultivate 
Pomegranate at large scale due to inavailability of quality planting materials. To ensure quality planting materials at low-cost, present study attempted to investigate the rooting ability of small leafy branch cuttings of $P$. granatum in farmers' friendly lowcost, non-mist propagator with or without rooting hormone (IBA) with the ultimate investigation of survival percentage of rooted cuttings (stecklings).
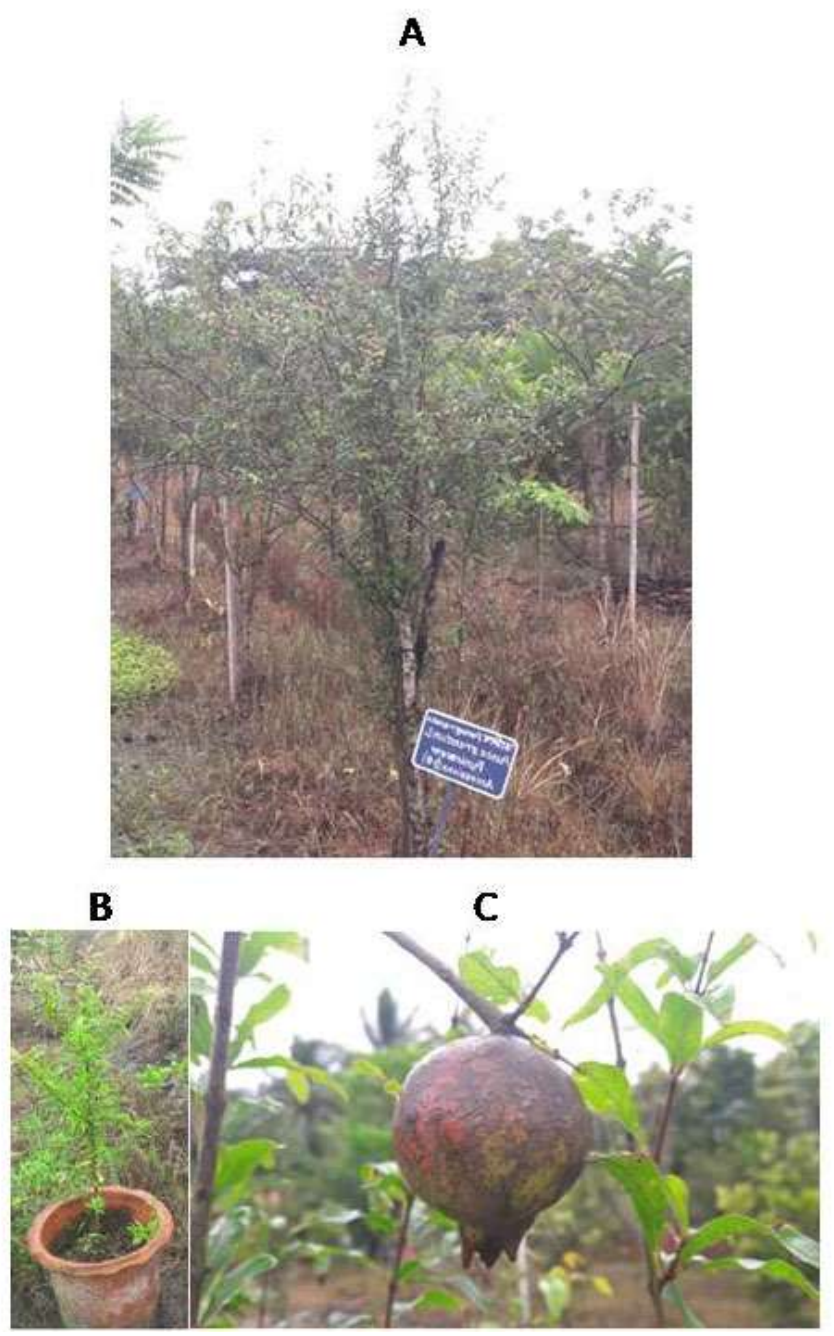

Figure 1. Full grown tree (a), 2 years old seedling at germplasm centre and ripe fruits of $P$. granatum

\section{Materials and Method}

\subsection{Study location, duration and climate}

The study was conducted during March, 2016 to April, 2017 at the Agriculture research field of Patuakhali Science and Technology University, Bangladesh (lies between $21^{\circ} 48^{\prime}$ and $22^{\circ} 36^{\prime}$ north latitudes and between $90^{\circ} 08^{\prime}$ and $90^{\circ} 41^{\prime}$ east longitudes) (Fig. 2) which enjoys typical tropical climate characterized by hot humid summer and cool dry winter. The average temperature ranged between $14.3^{\circ}$ to $27.4^{\circ} \mathrm{C}$ in winter and between $24.3^{\circ}$ to $33.6^{\circ} \mathrm{C}$ during summer from 2010 to 2014 (Fig. 3). The average annual rainfall was $2657 \mathrm{~mm}$ and varied from $1877 \mathrm{~mm}$ to $3120 \mathrm{~mm}$ and rainfall usually takes place between June and September (Fig. 3). The day length varies from $10 \mathrm{~h} 45 \mathrm{~min}$ in December to $13 \mathrm{~h} 25 \mathrm{~min}$ in June. Relative humidity is minimum $(64 \%)$ in February and maximum (95\%) in June to September. 


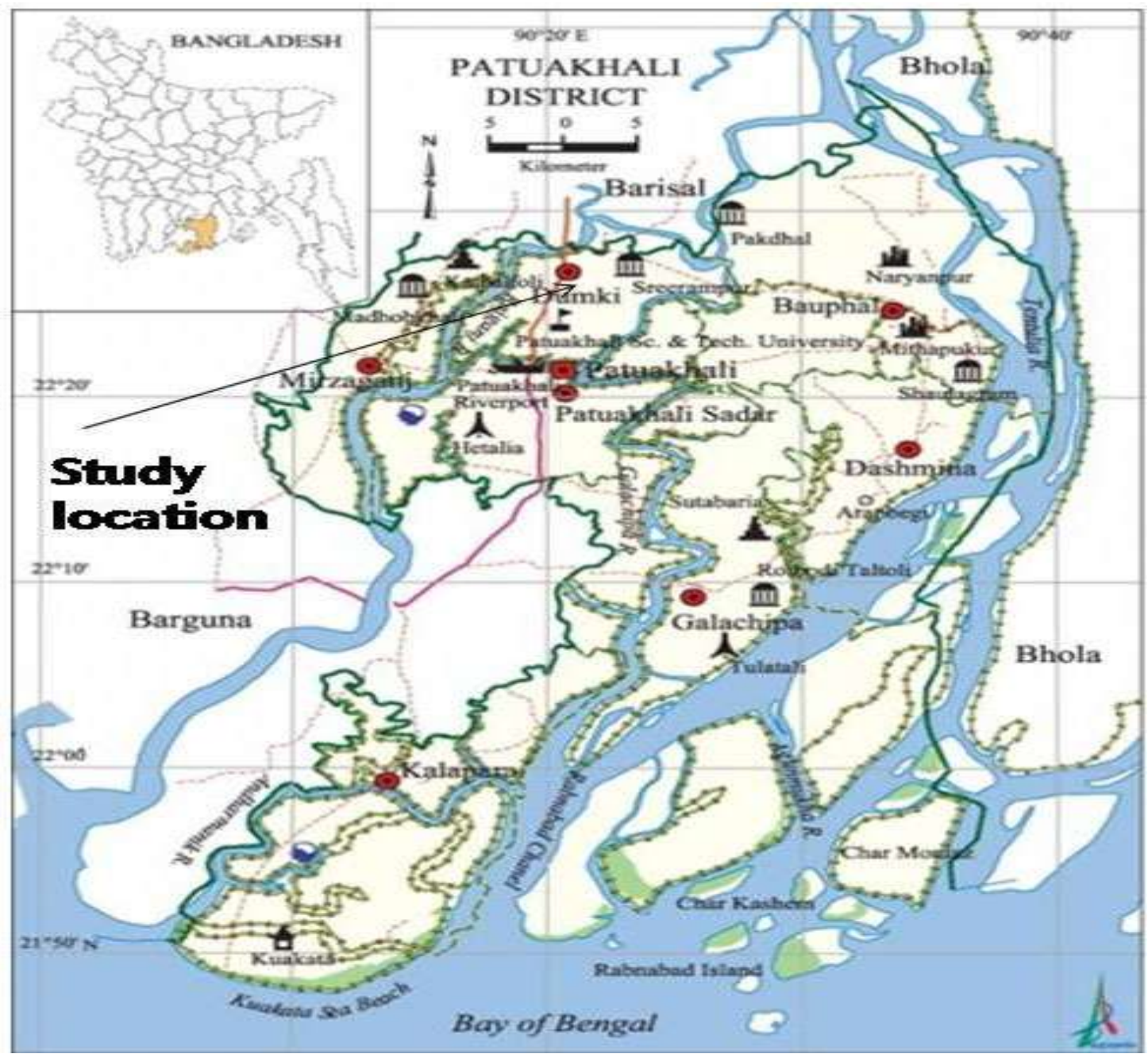

Figure 2. Geographical location of PSTU at Dumki Upazila

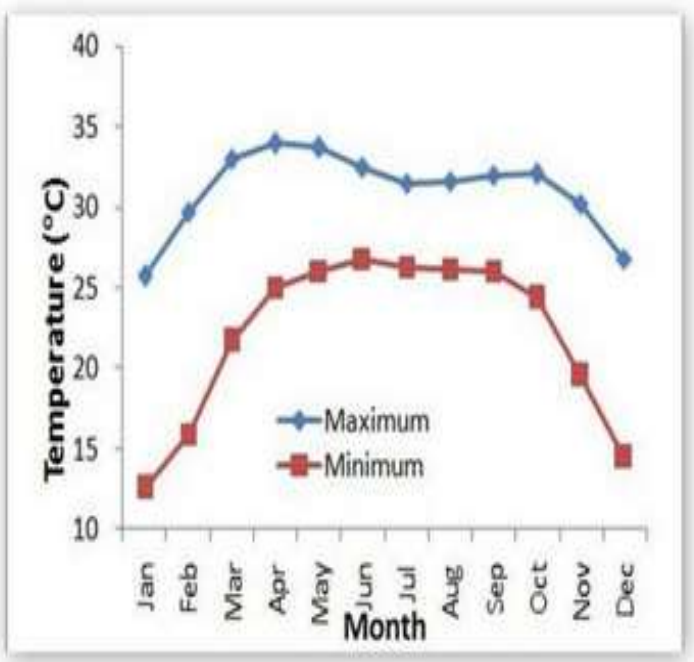

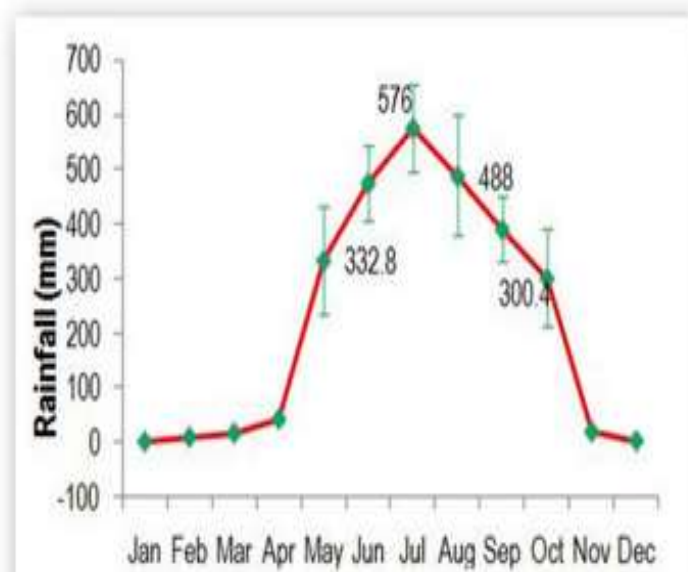

Month

Figure 3. Temperature and rainfall at Patuakhali region from data of conjugative 5 years (2010-2014) (Source: Khepupara meteorological station) 
Int. J. Agr. Syst. 5(2): 185-197 


\subsection{Preparation of stem cuttings and setting up the experiment}

The study on vegetative propagation was carried out in a low cost non-mist propagator (Fig. 4). The non-mist propagator was constructed following the design described by Leakey et al. (1990) modified by Kamaluddin (1996) and was covered with sheet of transparent polythene such that the base was completely watertight and the lid was also airtight. The polythene base of the propagator was covered with a 10 $\mathrm{cm}$ thick layer of moist coarse sand mixed with successive layers of fine gravels and small stones. This layer supported rooting media kept in perforated plastic trays.

Juvenile shoots of $P$. granatum were collected from 2-years old stock plants raised in the Germplasm Centre of PSTU to get quality propagules. Two-node stem cuttings were prepared keeping two leaves intact without any trimming (considering smaller leaf area of $P$. granatum) and then immersed briefly in a solution of fungicide Diathane M45 (Rohm and Co Ltd, France; $2 \mathrm{~g} / \mathrm{L}$ in water) to avoid fungal infection. The cuttings were then rinsed and kept under shade for 10 minutes in open air for drying.

As growth regulators are organic compounds that needed in the least amount which can support, inhibit, and may alter physiological processes of plants (Ulfa et al. 2015), stem cuttings were then treated with $0 \%$ (control), $0.2 \%, 0.4 \%$ and $0.8 \%$ IBA (Indole 3 Butyric Acid) solutions by dipping the cutting base into IBA solution to test effect of IBA on rooting ability and finally treated cuttings were planted into perforated pla stic trays (12 cm depth) filled with coarse sand (Sylhet sand) mixed with fine gravel following a Randomized Complete Block Design (RCBD).

A total of 160 cuttings were placed under four different treatments with four replications per treatment. Ten cuttings treated with same concentration of IBA were placed in each plastic tray and each tray served as an experimental plot. Thus the number of replication of cuttings per treatment was 40 . The cuttings were watered once only just after setting inside the propagator.

\subsection{Propagator environment, aftercare and transplanting}

The propagator was kept under bamboo made shed to avoid excessive heat accumulation. The propagator was opened briefly in the morning and in the late afternoon to facilitate gaseous exchange. Whenever the propagator lid was opened for observation, a fine jet of water spraying was applied to cuttings to maintain a low vapor pressure deficit inside the propagator. This resulted in a permanently humid environment throughout the propagation period (around $85 \%$ relative humidity).

The assessments of rooting success were carried out weekly after the first two weeks of cutting placement in the propagator. A cutting was considered as rooted when it had at least one root exceeding $1 \mathrm{~cm}$ long. The rooting of cuttings in the propagator completed within six weeks after putting the cuttings into the rooting media in propagator.

After four weeks in the rooting medium, the rooted cuttings in the propagator were weaned before transferring them in to poly bags, particularly towards the end of rooting period during root lignifications. For weaning, the propagator was kept open at night for three days and then at day and night for another three days. The wea ned rooted cuttings were then transferred into poly bags filled with soil and decomposed cow dung at a ratio of 3:1. Before planting into the poly bags, rooted cuttings were measured for rooting percentage, number of roots developed per cutting and the length of longest root. 


\subsection{Data analysis}

The experiment was laid out following a Randomized Complete Block Design (RCBD) with 4 treatments and 4 replications (blocks). Mean values for root number, root length and root diameter were calculated on experimental plot basis. All data were analyzed through computer based statistical program MSTAT-C (Michigan State University, East Lansing, MI, USA) following the basic principles, as outlined by Gomez and Gomez (1984). Significant effects of treatments were determined by analysis of variance (ANOVA) and treatment means were compared at $5 \%$ level of significance by Duncan's Multiple Range Test (DMRT). Microsoft 'Excel package' (Microsoft Corporation, Pullman, WA, USA) were used for correlation and regression analysis. Rooting percentage was calculated and values were adjusted accordingly using arc sign transformation formula before putting the data into Analysis of Variance since the percentages of cuttings rooted were distributed between the range of 30 to 100 and proportions were based on equal denominator.

A

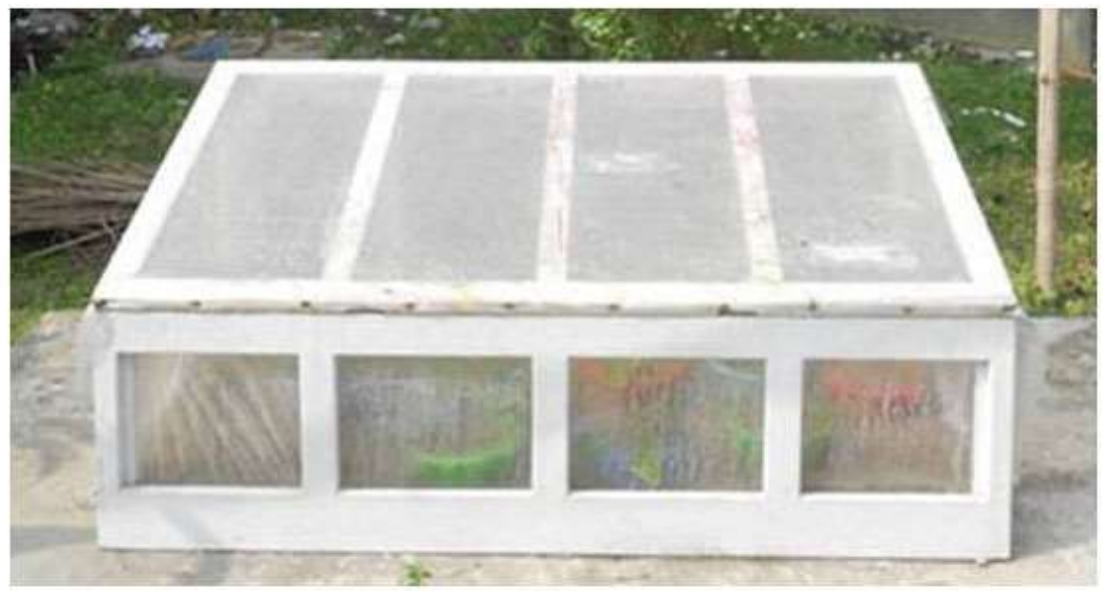

B

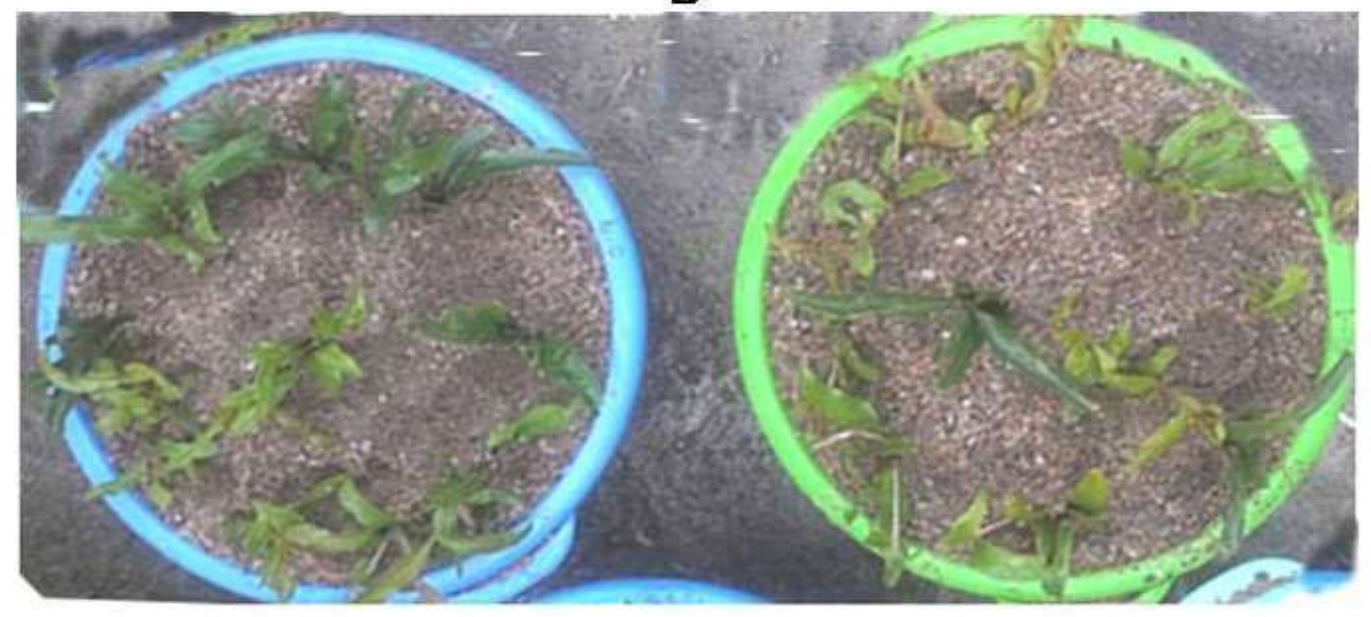

Figure 4. Non-mist wooden frame poly thene propagator containing perforated plastic trays after setting of the experiment (A), Plastic trays with rooted cuttings (B) 


\section{Results and Discussion}

\subsection{Rooting ability}

Rooting percentage of $P$. granatum cuttings was significantly enhanced by exogenous rooting hormone (IBA) (Fig. 5 and 6). The highest rooting percentage (70\%) was obtained from the cuttings treated with $0.2 \%$ IBA solution followed by the cuttings treated with $0.4 \%$ IBA $(47.5 \%)$ and $0.8 \%$ IBA $(45 \%)$ respectively. The lowest rooting percentage $(32.5 \%)$ was in cuttings without IBA treatment (control).

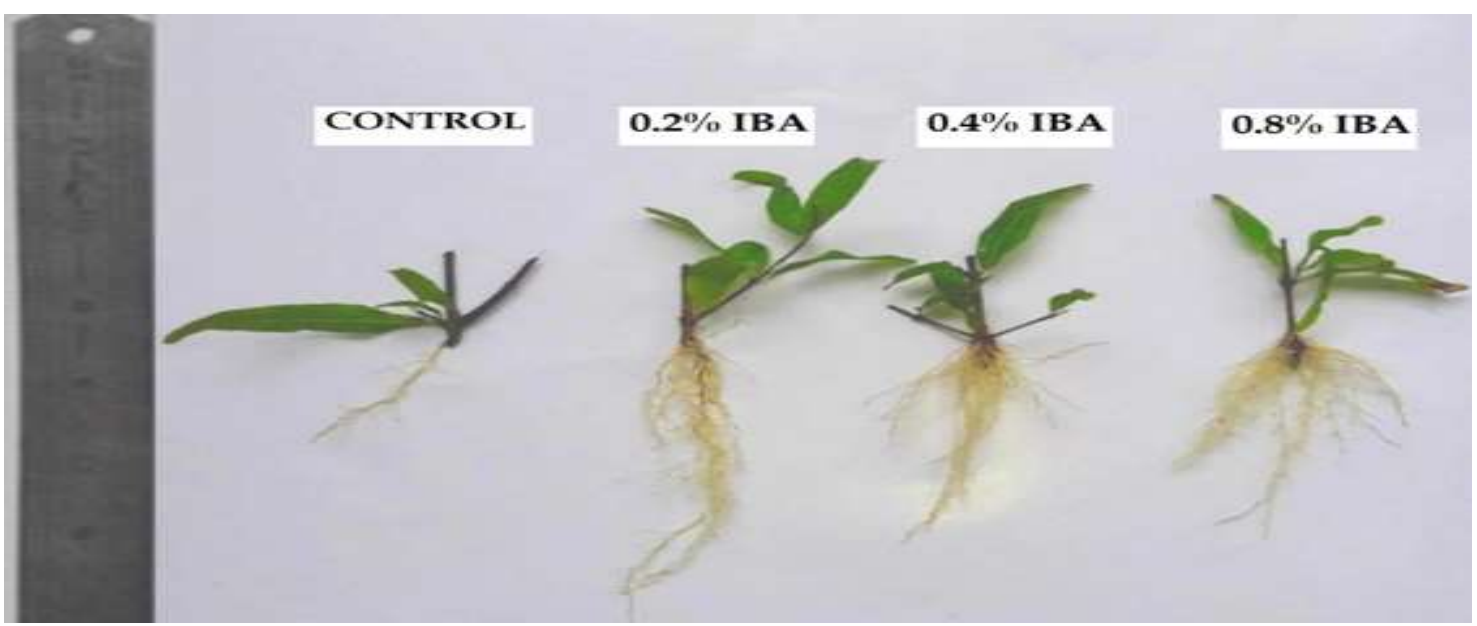

Figure 5. Rooting ability of cuttings of $P$. granatum under various IBA treatments

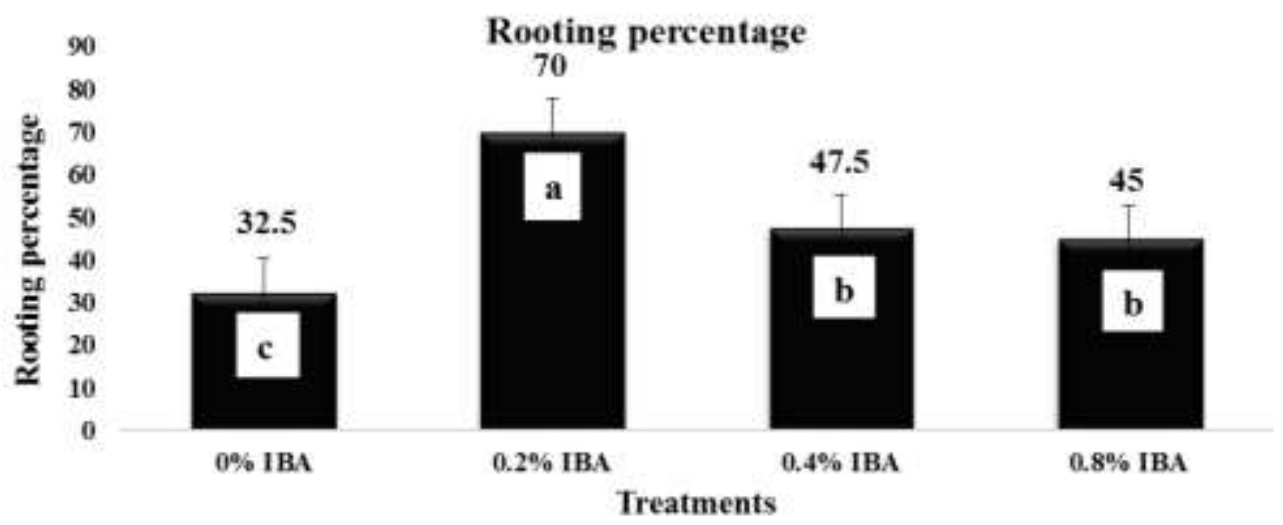

Figure 6. Rooting percentages of $P$. granatum stem cuttings under different IBA concentrations

Applied rooting hormone IBA is known to intensify the rooting percentage of cuttings as explained by many authors. The effect of IBA on rooting of cutting in various Pomegranate genotypes was studied in Turkey by Polat and Caliskan (2009) and found that the $1,000 \mathrm{ppm}(0.1 \%)$ IBA treated cutting had a slightly higher rooting percentage than the control.

The effect of IBA on the rooting of tachi-brancho (Sclerolobium paniculatum) cuttings was investigated by Rosa et al. (1997) and observed that the cuttings treated with $4000 \mathrm{ppm}(0.4 \%)$ IBA were rooted best, whereas cuttings without treatment rooted worst. The enhanced hydrolytic activity in presence of applied IBA coupled with appropriate planting time might be responsible for the increased percentage of rooted cuttings. 


\subsection{Root number}

Root number of cuttings was significantly enhanced due to the effect of applied IBA (Fig. 7). The highest number of root (32) was developed in $0.4 \%$ IBA treated cuttings and lowest (6) was in cuttings without IBA treatment. The findings of several a uthors support the result of the present study that enhanced number of roots developed due to the IBA treatment. The effect of IBA concentrations on the rooting of Pomegranate (P. granatum L.) hardwood cuttings was studied in Uttarakhand (India) by Singh (2017) and found that significantly higher number of primary roots per cutting was produced under 4g.L-1 concentration of IBA than the control. Kabir et al. (2017) also observed same trend for root number for IBA treated cuttings of Flacourtia indica.

The above finding also agrees with the finding of Koyunce and Senel (2003) for Black mulberry (Morus alba L.) in respect to average number of primary roots per cutting. Kamaluddin et al. (1996) recorded significant increases both in percentage rooting and number of roots with the application of IBA for Artocarpus heterophyllus.

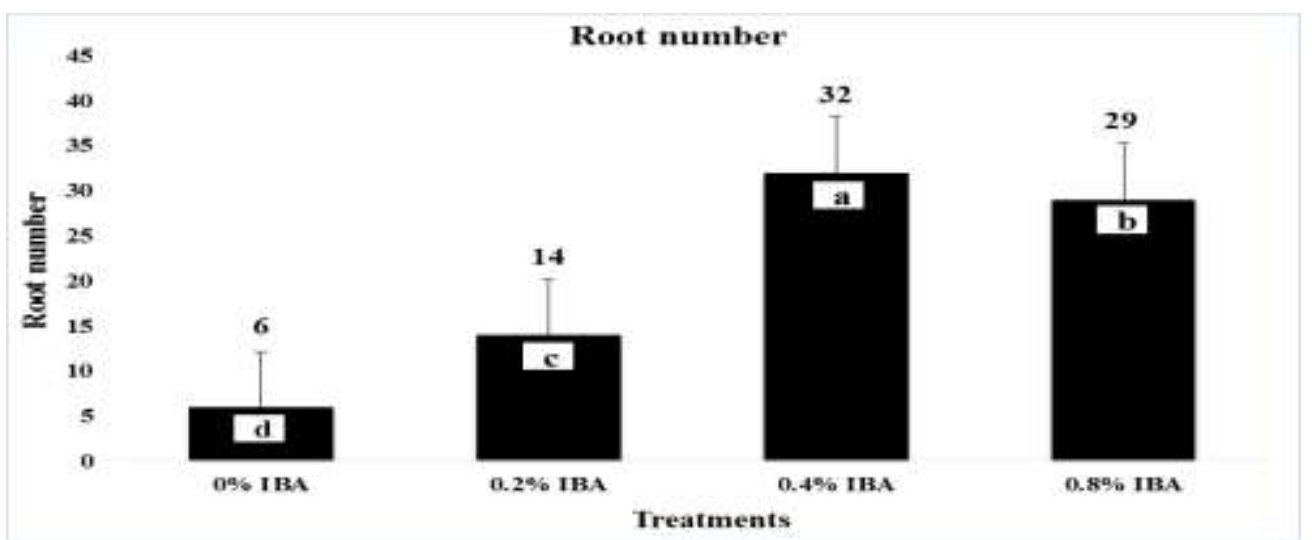

Figure 7. Root numbers of $P$. granatum cuttings developed under various IBA concentrations

\subsection{Root length}

Root length was significantly influenced with the increasing IBA concentrations (Fig. 8 and 9). The longest root $(11.75 \mathrm{~cm}$ ) was found in cuttings treated with $0.2 \%$ IBA, whereas the shortest root $(5.85 \mathrm{~cm})$ was recorded from the cutting without IBA treatment. Similar result was reported by Kabir et al. (2017) for Flacourtia indica and Abdullah et al. (2005) for Baccaurea sapida. It is evident from the present study that the cutting of $P$. granatum rooted even without any IBA treatment $(32.5 \%)$. However, the rooting ability of cutting in respect to rooting percentage, root number and root length was significantly enhanced with the applications of $0.2 \%$ to $0.8 \%$ IBA solution. Applied rooting hormone (IBA) increased rooting ability of cutting was reported by several researchers including Reddy and Reddy (1990); Hore and Sen (1995); Navjot Kahlon (2002); Scaloppi and Martins (2004); Tripathi and Shukla (2004) and Ram et al. (2005). 


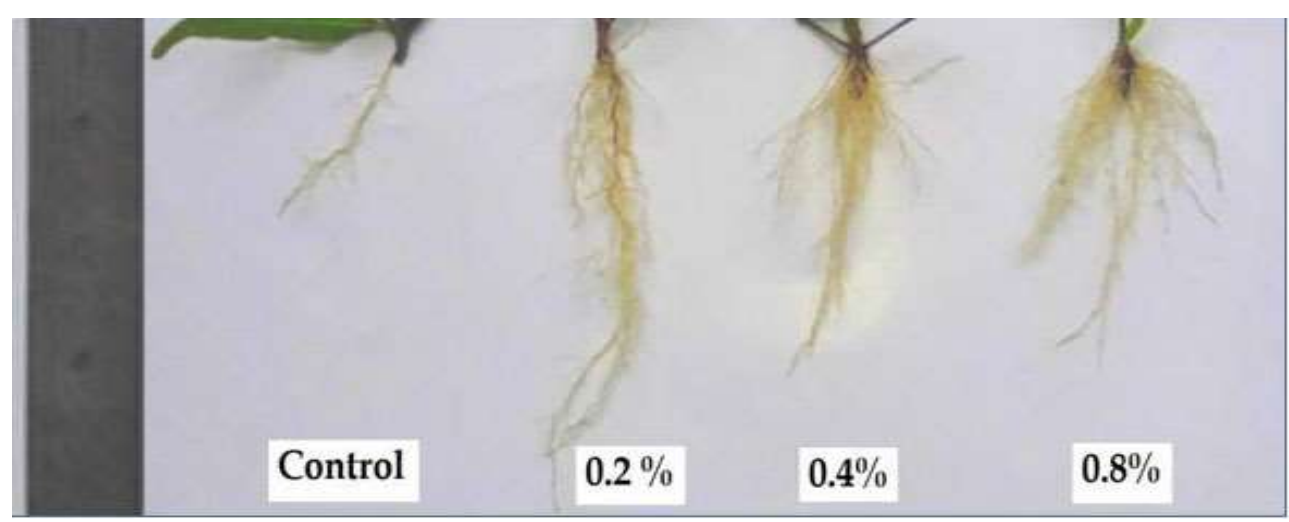

Figure 8. Longest root length recorded for different concentrations of IBA

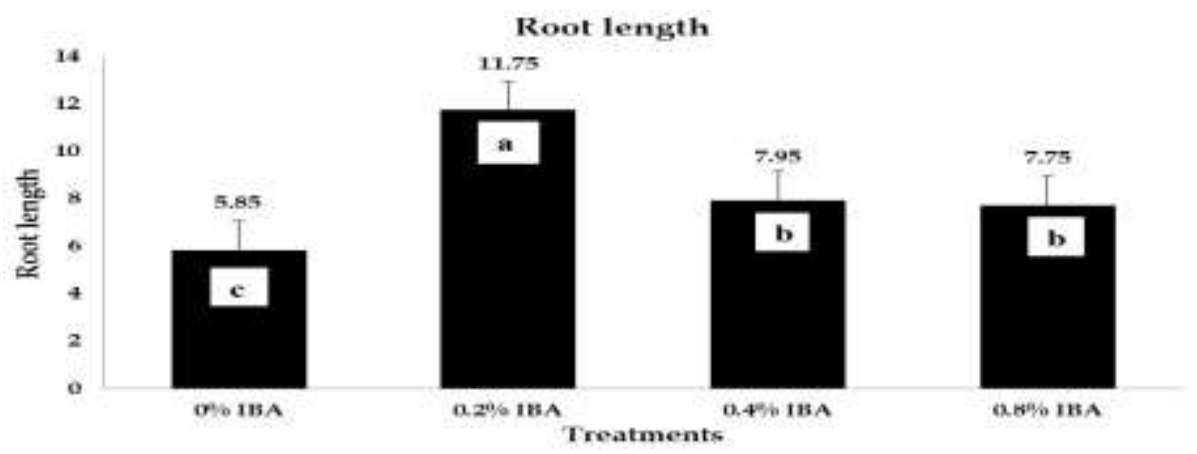

Figure 9. Root lengths of $P$. granatum cuttings developed under various IBA concentrations after six weeks from setting of the experiment

\subsection{Root diameter}

Root diameter was significantly influenced with the increasing IBA concentration (Fig. 10). The maximum diameter of roots $(2.7 \mathrm{~mm})$ was recorded under $0.4 \%$ concentration of IBA followed by $0.8 \%$ IBA $(2.47 \mathrm{~mm})$ and the minimum root diameter $(0.95 \mathrm{~mm})$ was recorded under control. These finding were similar to the finding of Singh (2017). Auxin application has been found to enhance the histological features like formation of callus and tissue and differentiation of vascular tissue (Mitra and Bose, 1954).

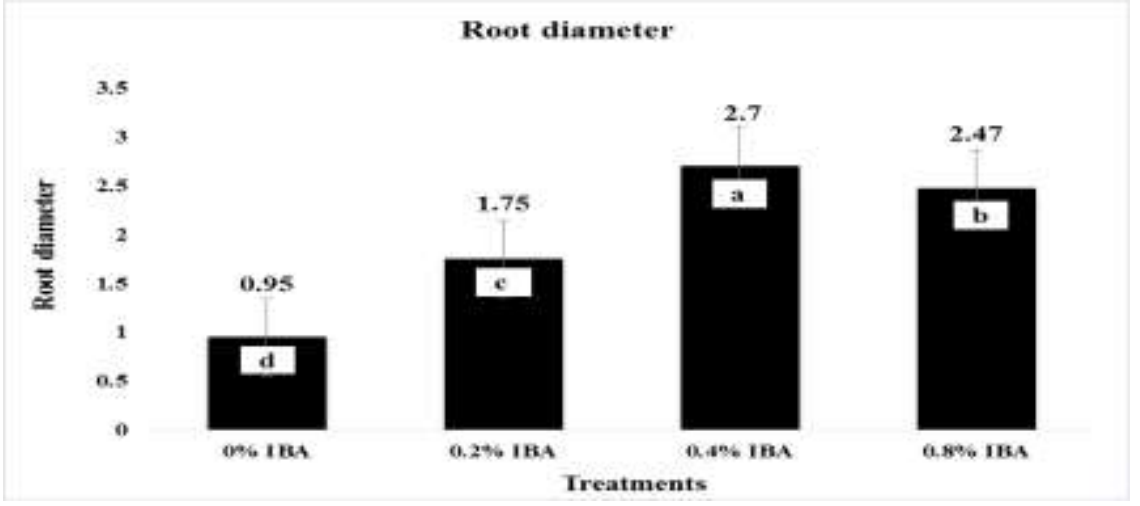

Figure 10. Root diameter of $P$. granatum cuttings developed under various IBA concentrations after six weeks from setting of the experimen 
Applied auxin is known to intensify root-forming process in cutting for instance, polysaccharide hydrolysis is activated under the influence of applied IBA, as a result the contents of psychologically active sugar increases providing materials for meristamatic tissues and later for root primordia and roots. Hassig (1983) examined the function of endogenous root forming components of plants, which had auxin components and non-auxin components. He demonstrated the auxin components $w$ as required for development of callus in which root primordia initiated, but for subsequent primordial development both auxin and non-auxin components were needed. It may be possible that in cutting with optimum amount of endogenous a uxin content and increasing of root number reflected the effect of applied auxin.

\subsection{Steckling capacity}

Survival percentage of the cutlings (the rooted cuttings) significantly enhanced by exogenous rooting hormone (IBA) application (Fig. 11 and 12). The highest survival percentage $(73.5 \%)$ was observed for the cuttings treated with $0.4 \%$ IBA followed by $0.8 \%$ IBA (68.5\%). The result is in accordance with the result for Flacourtia jangomas by Hossain et al. (2011) and for Flacourtia indica by Kabir et al. (2017) applying rooting hormone IBA using similar type of non-mist plant propagator.

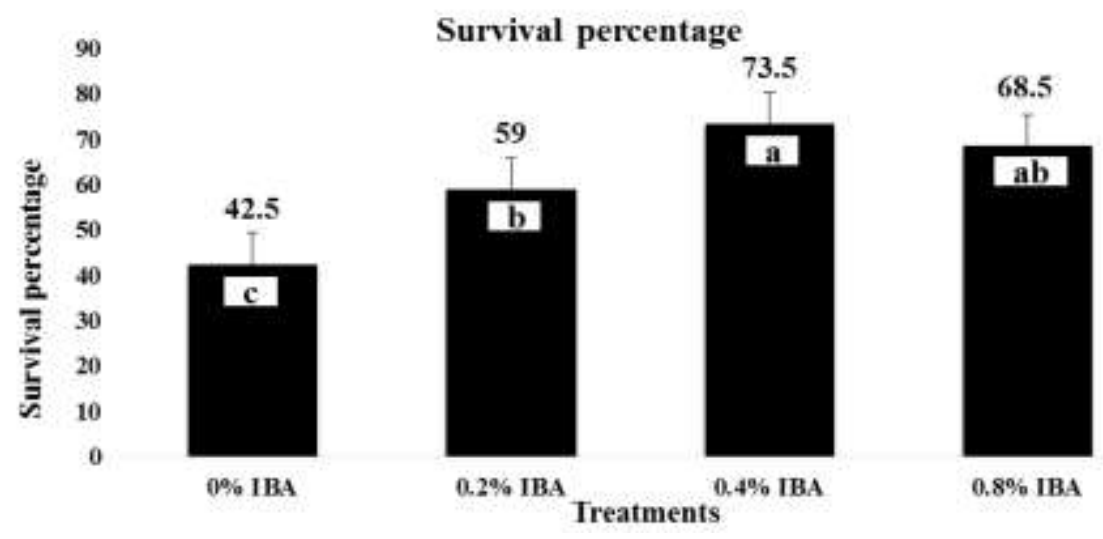

Figure 11. Survival percentage of $P$. granatum cutlings developed under various IBA concentrations three months after transferring into plastic pots

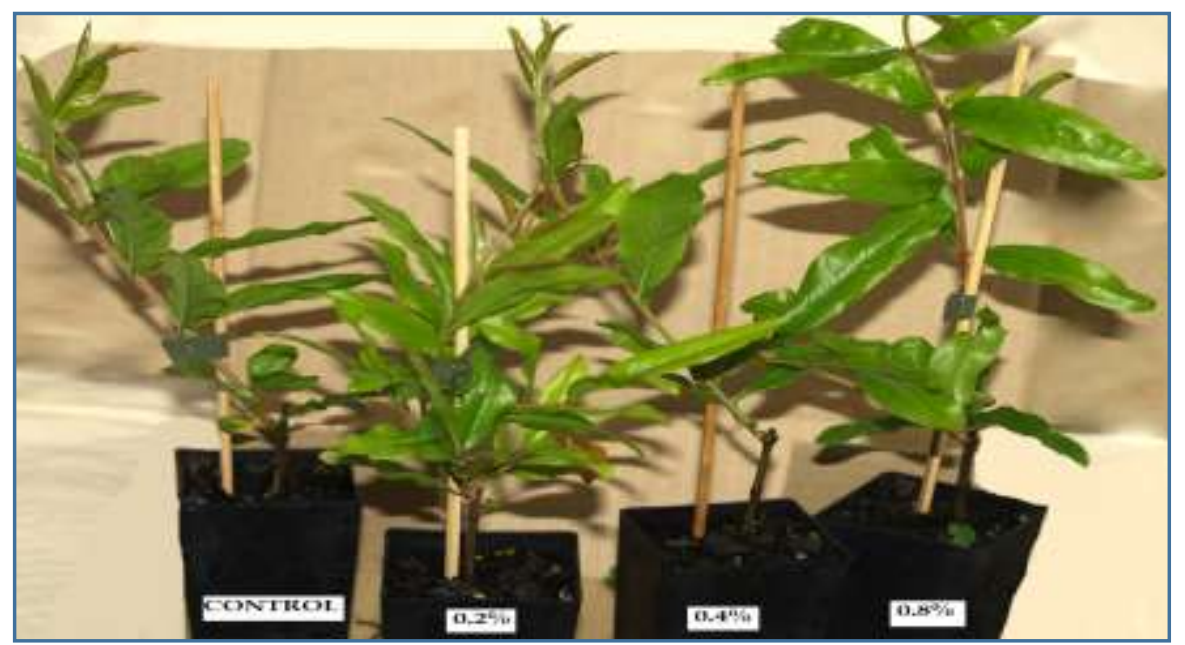


Figure 12. Growth performance of $P$. granatum cuttings rooted due to IBA treatment three months after transferring into plastic pot

\section{Conclusion}

Inadequacies of quality planting materials remain the major constraints for establishing large scale plantation programs of $P$. granatum in Bangladesh and other tropical countries. Due to scarcity of fruits or seeds, vegetative propagation through stem cutting can be a better and helpful option of multiplication. In the present study, $P$. granatum was found amenable for clonal propagation through stem cutting with application of rooting hormone IBA using low-cost non-mist propagator. Considering significantly higher rooting percentage, larger root diameter and higher survival percentage, $0.4 \%$ IBA is recommended for large scale multiplication of P. granatum. Considering farmers perception regarding desirable fruit characteristics (taste, seize, color), disease resistance and tree morphology, quality planting materials of $P$. granatum will inspire farmers to plant more $P$. granatum at their homesteads as well as to establish orchards for commercial production. Many tropical countries like Bangladesh which is at great risk of climate change and resultant natural disasters, large scale production of Pomegranate at homestead or in orchard will ensure food security as well as fulfill nutritional demand of poor people.

\section{References}

Abdelrahman, S. and A. AI-Wasel, (1999). In vitro clonal propagation of AI-Belehi pomegranate (Punica granatum L.). Journal of King Saud University. Agricultural Science, 11:3-14.

Abdullah, A.T.M., M.A. Hossain and M.K. Bhuiyan, (2005). Propagation of Latkan (Baccaurea sapida Muell. Arg.) by Mature Stem Cutting. Research Journal of Biological Sciences, 1(2): 129-134.

Aviram, M., M. Rosenblat, D. Gaitini, S. Nitecki, A. Hoffman, L. Dornfeld, N. Volkova, D. Presser, J. Attitas and H. Liker, (2004). Pomegranate juice consumption for 3 years by patients with carotid artery stenosis reduces common carotid intimamedia thickness, blood pressure and LDL oxidation. Clinical Nutrition, 23: 423433.

Hassig, B.E., (1983). The rooting stimulus in pine cuttings. Combined Proceedings, International Plant Propagators' Society, 32: 625-638.

Hoang, L.T, J.M. Roshetko, T.P. Huu, T. Pagella and P.N. Mai, (2017). Agroforestry The Most Resilient Farming System for the Hilly Northwest of Vietnam. International Journal of Agriculture System, 5(1):1-23.

Hore, J.K. and S.K. Sen, (1995). Role of non-auxinic compounds and IBA on root regeneration in air-layers of pomegranate. Current Research, University of Agricultural Sciences, Bangalore, 24: 83-85.

Hossain, M.A., M. Sen, M.I.U. Jewel and M.A. Kabir, (2011). Propagation of Flacoutia jangomas: an approach towards the domestication of a wild fruit species in Bangladesh. Dendrobiology, 65: 63-71.

Kabir, M. A., M.H.M. Khan, M.M. Rahman, A.R. Alam, S.H. Jahan, A.K.M.M. Zaman and M.Z. Al Mamun, (2017). Clonal Propagation of Flacourtia indica for Ensuring Quality Planting Materials and Sustainable Supply of Edible Fruits. International Journal of Agriculture System, 5(1): 42-52. 
Kamaluddin, M., (1996). Clonal propagation of Eucalyptus and Acacia hybrid by stem cuttings. Research report, Institute of Forestry and Environmental Sciences, University of Chittagong, Bangladesh.

Kamaluddin, M., M. Ali and M.K. Bhuiyan, (1996). Effect of auxin on rooting and growth of stecklings of jackfruit (Artocarpus heterophyllus). Chittagong Univ Stud Part II: Science, 20(1): 71-75.

Karimi, H.R. and S.H. Mirdehghan, (2013). Correlation between the morphological characters of pomegranate (Punica granatum) traits and their implications for breeding. Turkish Journal of Botany, 37: 355-362.

Kaur, S. and A. Kaur, (2016). Effect of IBA and PHB on rooting of pomegranate (Punica granatum L.) cuttings cv. Ganesh. Biological Forum - An International Journal, $8(2): 203-206$.

Koyunce, F. and E. Senel, (2003). Rooting of Black Mulberry (Morus alba L.) Hardwood cutting. Journal of Fruit and Ornamental Plant Research, 11:53-55.

Leakey, R.R.B., J.F. Mesen, Z. Tchoundjeu, K.A. Longman, J.Mc.P. Dick, A. Newton, A. Matin, J. Grace, R.C. Munro and P.N. Muthoka, (1990). Low technology techniques for the vegetative propagation of tropical trees. Commonwealth Forestry Review, 69: 247-257.

Mitra, G.C. and N. Bose, (1954). Rooting and histological responses of detached leaves to B- Indolebutyric acid with special reference to Boerhavia diffusa Linn. Phytomorphology, 7:370.

Navjot Kahlon, P.S., (2002). Effect of type of cutting and IBA on rooting in cuttings and plant growth in pomegranate (Punica granatum) cv. Kandhari. Horticulture Journal, 15(3): 9-16.

Negi, P.S., G.K. Jayaprakasha and B.S. Jena, (2003). Antioxidant and antimutagenic activities of pomegranate peel extracts. Food Chemistry, 80:393-397.

Polat, A.A. and O. Caliskan, (2009). Effect of indolebutyric acid (IBA) on the rooting cutting in various pomegranate genotypes. Acta Horticulturae (ISHS), 818: 187192.

Ram, R.B., P. Kumar, and A. Kumar, (2005). Effect of IBA and PHB on regeneration of pomegranate (Punica granatum L.) through stem cuttings. New Agriculturist, 16(1/2): 113-115.

Reddy, Y.N. and Y.T.N. Reddy, (1990). Effects of basal wounding, growth regulator and polythene covering on rooting of pomegranate cutting. Journal of Maharashtra agricultural universities, 15: 153-155.

Rosa, L. and S. Dos, (1997). Promotion of rooting in stems cuttings of tachi-branco (Sclerolobium paniculatum Vogel) by application of different concentrations of indole-3 -butyric acid, Boletim da Faculdade de Ciencies Agraries do Para. 28:81 91.

Rymbai, H. and G.S. Reddy, (2010). Effect of IBA, time of layering and rooting media on air-layers and plantlets survival under different growing nursery conditions in guava. Indian Journal of Horticulture, 67: 99-104.

Scaloppi E.M.T. and A,B.G. Martins, (2004). Clonal propagation of pomegranate (Punica granatum) by cuttings. Proceedings of the Interamerican Society for Tropical Horticulture, 47: 275-276.

Seeram, N.P., L.S. Adams, S.M. Henning, Y. Niu, G. Zhang, M.G. Nair and D. Heber, (2005). In vitro antiproliferative apoptotic and antioxidant activities of punicalagin, ellagic acid and a total pomegranate tannin content are enhanced in 
combination with other polyphenols as found in pomegranate juice. The Journal of Nutritional Biochemistry, 16: 360-367.

Singh, K.K., (2017). Effect of IBA concentrations on the rooting of pomegranate (Punica granatum L.) cV. Ganesh hardwood cuttings under mist house condition. International Journal of Horticulture and Floriculture 5(4): 318-323.

Tripathi, S.N. and H.S. Shukla, (2004). Propagation of pomegranate (Punica granatum L.) cultivars by stem cutting with indole butyric acid and p-hydroxybenzoic acid. Indian Journal of Horticulture, 61(4): 362-365.

Ulfa, F., E.L. Sengin, B. Baharuddin, S.A. Syaiful, N.R. Sennang, R. Rafiuddin, N. Nurfaida and I. Ifayanti, (2015). Potential of Plant Extracts as Growth Exogenous Regulators of Potato Seeds. International Journal of Agriculture System (IJAS), 1(2): 98-103. 